\title{
Novel dipeptidyl proteasome inhibitors overcome Bcl-2 protective function and selectively accumulate the cyclin-dependent kinase inhibitor p27 and induce apoptosis in transformed, but not normal, human fibroblasts
}

\author{
Bing $\mathrm{An}^{1,3}$, Ronald H. Goldfarb ${ }^{2,3}$, Robert Siman ${ }^{4}$ and \\ Q. Ping Dou ${ }^{1,3,5}$ \\ 1 The Department of Pharmacology, University of Pittsburgh School of \\ Medicine, Pittsburgh, Pennsylvania, USA \\ 2 The Department of Pathology, University of Pittsburgh School of Medicine, \\ Pittsburgh, Pennsylvania, USA \\ ${ }^{3}$ University of Pittsburgh Cancer Institute, 200 Lothrop Street, Pittsburgh, \\ Pennsylvania 15213-2582, USA \\ ${ }^{4}$ Cephalon, Inc., 145 Brandywine Parkway, West Chester, Pennsylvania 19380 , \\ USA \\ ${ }^{5}$ corresponding author: Q. Ping Dou, Ph.D. Present address: Drug Discovery \\ Program, Department of Biochemistry and Molecular Biology, H. Lee Moffitt \\ Cancer Center \& Research Institute at the University of South Florida, 12902 \\ Magnolia Drive, Tampa, Florida 33612-9497, USA Tel: (813) 632 1437; \\ Fax: (813) 979 6748; e-mail: douqp@moffitt.usf.edu
}

Received 19.2.98; revised 9.6.98; accepted 23.6.98

Edited by C.J. Thiele

\begin{abstract}
It has been suggested that overexpression of the $\mathrm{Bcl}-2$ oncoprotein in human cancer cells contributes to their resistance to apoptosis induced by chemotherapy. We report here that a novel dipeptidyl proteasome inhibitor, CEP1612, at low concentrations rapidly induces apoptosis in human Jurkat T cells overexpressing Bcl-2 and also in all human prostate, breast, tongue and brain tumor cell lines we have tested to date, without exception. In contrast, etoposide, a standard anticancer drug, fails to kill these cells when employed under the same conditions. The apoptosis-inducing abilities of CEP1612 and its analogous compounds match precisely their order for inhibition of the proteasome chymotrypsin-like activity. CEP1612-induced apoptosis is p53-independent, inhibitable by a tetrapeptide caspase inhibitor, and associated with accumulation of the cyclindependent kinase inhibitors p21 and p27. Furthermore, CEP1612 selectively accumulates p27 and induces apoptosis in simian virus 40-transformed, but not the parental normal, human fibroblasts. Proteasome inhibitors such as those investigated herein might therefore have potential use as novel anticancer drugs.
\end{abstract}

Keywords: anticancer drugs; apoptosis; Bcl-2; drug resistance; human cancers; p21; p27; proteasome inhibitors
Abbreviations: CEP1612, phthalimide- $\left(\mathrm{CH}_{2}\right)_{8} \mathrm{CH}$ (cyclopentyl) CO-Arg $\left(\mathrm{NO}_{2}\right)$-Leu-H; CEP1508, cyano- $\left(\mathrm{CH}_{2}\right)_{8} \mathrm{CH}$ (cyclopentyl) CO-Arg $\left(\mathrm{NO}_{2}\right)$-Leu-H; CMPD 8, Compound 8, cyano- $\left(\mathrm{CH}_{2}\right)_{8}$ $\mathrm{CH}$ (cyclopentyl) CO-Arg $\left(\mathrm{NO}_{2}\right)$ - Leu - $\mathrm{N}$ - ethyl-ketoamide; LLnL, $\mathrm{N}$-acetyl-L-leucyl-L-leucyl-norleucinal; LLnV, $\mathrm{N}$-carbobenzoxy-Lleucyl-L-leucyl-norvalinal; p21, Waf1/Cip1/Sdi1; p27, Kip1; PARP, poly(ADP-ribose) polymerase; RB, retinoblastoma protein; VP-16, etoposide; YVAD-CMK, acetyl-YVAD-chloromethyl ketone

\section{Introduction}

Apoptosis is an active process of programmed cell death that is conserved throughout evolution from worm to man (Jacobson et al, 1997). Apoptosis occurs in two physiological stages, commitment and execution. The apoptotic execution is initiated by activation of specific proteases of caspase family, which exhibit a rather unique substrate specificity, cleavage after Asp residues (Martin and Green, 1995). To date, at least elevan homologs of caspases have been identified and cloned (Alnemri et al, 1996; Wang et al, 1998). Activation of caspases leads to apoptosis probably through the proteolytic cleavage of several important cellular proteins, i.e. poly(ADP-ribose) polymerase or PARP (Lazebnik et al, 1994). We (An and Dou, 1996; Fattman et al, 1997) and others (Janicke et al, 1996; Tan et al, 1997; Chen et al, 1997) also reported that during apoptosis the tumor suppressor retinoblastoma $(\mathrm{RB})$ protein is proteolytically cleaved in both interior region and $\mathrm{C}$-terminus by caspases. In addition, we (Dou et al, 1995) and others (Morana et al, 1996; Day et al, 1997) also reported RB dephosphorylation prior to the onset of apoptotic execution.

Activation of the cellular apoptotic program is a current strategy for treatment of human cancers. It has been demonstrated that irradiation and standard chemotherapeutic drugs kill some tumor cells through induction of apoptosis (Fisher, 1994). Unfortunately, the majority of human cancers at present are resistant to these therapies (Harrison, 1995; Desoize, 1994; Kellen, 1994). Although the molecular mechanisms for development of such multidrug resistance in human cancers are unclear, it has been suggested that overexpression of Bcl-2 (Desoize, 1994; Wang and Reed, 1998) or inactivation of the tumor suppressor protein p53 (Kellen, 1994) are involved in this process.

The ubiquitin-proteasome system plays an important role in the degradation of cellular proteins (Hochstrasser, 1995). Most recent studies have also suggested that the ubiquitin- 
proteasome system is involved in the regulation of apoptosis, although its postulated roles remain controversial. It has been found that some proteasome inhibitors block the apoptotic process in thymocytes (Grimm et al, 1996) and neurons (Sadoul et al, 1996). These proteasome inhibitors include lactacystin, a microbial metabolite, and tripeptide aldehydes, such as $\mathrm{N}$-acetyl-L-leucyl-L-leucylnorleucinal (LLnL) and $N$-carbobenzoxy-L-leucyl-L-leucylnorvalinal (LLnV). In contrast, the same or similar proteasome inhibitors have been found to induce apoptosis in human or mouse leukemia (Imajoh-Ohmi et al, 1995; Shinohara et al, 1996; Drexler, 1997; Tanimoto et al, 1997) and other proliferating cell lines (Lopes et al, 1997).

Our interest in both apoptosis and proteasome in various aspects of tumor cell biology (Dou, 1997; Wasserman et al, 1994; Iqbal et al, 1995) promoted our current study. Previously we have reported the synthesis and characterization of dipeptidyl aldehyde and $\alpha$-ketoamide inhibitors of the proteasome (lqbal et al, 1995, 1996; Harding et al, 1995). These inhibitors exhibited improved selectivity for the chymotrypsin-like activity over the trypsin-like activity of the proteasome (Iqbal et al, 1996; Harding et al, 1995). In addition, these inhibitors also showed a much lesser capacity to inhibit the activities of cysteine proteases, such as calpain I and cathepsin B (Harding et al, 1995). Here we report that one of these novel proteasome inhibitors, CEP1612 [phthalimide- $\left(\mathrm{CH}_{2}\right)_{8} \mathrm{CH}$ (cyclopentyl) CO-Arg $\left(\mathrm{NO}_{2}\right)$-Leu-H; Harding et al, 1995], rapidly induced apoptosis in human leukemic cells, as determined by multiple apoptosis assays. The rank order of the apoptosis-inducing abilities of a series of these proteasome inhibitors was similar to that of their inhibitory potency toward the chymotrypsin-like activity of the proteasome reported previously (Iqbal et al, 1995, 1996; Harding et al, 1995). CEP1612 has greater apoptosis-inducing potency than etoposide (VP-16), a currently used anticancer drug, when tested in human leukemia and other tumor cell lines from prostate, breast, tongue and brain. Induction of apoptosis by CEP1612 was p53-independent and blocked by addition of a tetrapeptide caspase inhibitor, but not by expression of the $\mathrm{Bcl}-2$ oncoprotein. Accompanying CEP1612-induced apoptosis in human breast cancer cells, the level of the cyclin-dependent kinase inhibitor p21 (Waf1/Cip1/Sdi1) was dramatically increased at an early stage, followed by accumulation of p27 (Kip1). Finally, CEP1612 selectively accumulated p27 and induced apoptosis in simian virus 40 (SV40)-transformed, but not the parental normal, human fibroblasts.

\section{Results \\ Induction of apoptosis and activation of caspases by dipeptidyl proteasome inhibitors in human leukemia cells}

We tested the hypothesis that the proteasome is involved in the survival signaling pathway(s) and that inhibition of the proteasome activity by specific inhibitors induces apoptosis. When human Jurkat $\mathrm{T}$ cells were treated with $30 \mu \mathrm{M}$ CEP1612 for $4 \mathrm{~h}$, apoptosis occurred, as demonstrated by appearance of an apoptotic population with sub-G $_{1}$ DNA content (Figure $1 \mathrm{~b}$ vs a), condensation and fragmentation of nuclei (comparable to Figure $4 \mathrm{~b} v s$ a) and the internucleosomal fragmentation of DNA (data not shown and see Figure $1 \mathrm{~g})$. The CEP1612 treatment also induced the processing of caspase-3 (CPP32), which is required for its activation (Martin and Green, 1995), cleavage of PARP to a p85 fragment, and cleavage of $R B$ to a p68 fragment (Figure $1 d-f$, lanes 2 vs 1 ). The same treatment also induced the processes of RB Cterminal cleavage and dephosphorylation, as evidenced by production of the C-terminal truncated ( $\mathrm{p} 112)$ and hypophosphorylated ( $p 115$ ) forms of RB (Figure 1f, lanes 2 vs 1; also see Figure $5 d$, lane 5 ). In this and the following studies, we combined both the p112 and p115 forms of RB as p112-115/ $\mathrm{RB}$ and used them as an apoptosis indicator. All of the above apoptotic events were also observed when human leukemia HL-60 cells were treated with a dipeptidyl proteasome inhibitor. For example, exposure of HL-60 cells to CEP1612 for $4 \mathrm{~h}$ (data not shown), or to another similar proteasome inhibitor CEP1508 [cyano- $\left(\mathrm{CH}_{2}\right)_{8} \mathrm{CH}$ (cyclopentyl)CO$\operatorname{Arg}\left(\mathrm{NO}_{2}\right)$-Leu-H; Harding et al, 1995] for $24 \mathrm{~h}$ (Figure 1g), induced internucleosomal fragmentation of DNA. Since both human Jurkat T (Iwamoto et al, 1996) and HL-60 cells (Danova et al, 1990) contain mutant p53 genes, dipeptidyl proteasome inhibitor-induced apoptosis must be p53-independent.

To provide additional evidence for involvement of caspase activation in dipeptidyl proteasome inhibitorinduced apoptosis, we used acetyl-YVAD-chloromethyl ketone (YVAD-CMK), a tetrapeptide inhibitor that inhibits some caspase activities in cell-free systems (Thornberry et al, 1992; Lazebnik et al, 1994) and also prevents apoptosis in some cell systems (Enari et al, 1995; An and Dou, 1996). Addition of YVAD-CMK into CEP1612-treated Jurkat T cells completely blocked production of the apoptotic peak (Figure 1c vs b), processing of caspase-3, cleavage of PARP, and dephosphorylation and cleavage of RB (Figure 1d-f, lanes 3 vs 2), demonstrating that a sensitive caspase(s) are located upstream of these events.

\section{The apoptosis-inducing abilities of dipeptidyl proteasome inhibitors match precisely their order for inhibition of the proteasome chymotrypsin-like activity}

To demonstrate that dipeptidyl proteasome inhibitor-induced apoptosis is due to blockade of proteasomal activity, and is not due merely to compound toxicity or inhibition of another protease, the potencies of a series of compounds as inhibitors of the chymotrypsin-like activity of the proteasome were compared with their cell killing abilities. The cell killing ability of a compound was measured by its effective concentration that kills $50 \%$ of cells $\left(E_{50}\right)$. In this experiment, human Jurkat T cells were treated for $24 \mathrm{~h}$ with a proteasome inhibitor at different concentrations, and cell viability was assessed. As shown in Table 1, the rank order potency for induction of Jurkat cell death was CEP1612>CEP1508=CEP1513 $>$ Compound 8 [CMPD 8; cyano- $\left(\mathrm{CH}_{2}\right)_{8} \mathrm{CH}$ (cyclopentyl) CO$\operatorname{Arg}\left(\mathrm{NO}_{2}\right)$-Leu-N-ethyl-ketoamide] $>>$ CEP1601. This matches precisely the order for inhibition of the chymotryp- 
Table 1 Pharmacologic properties of inhibitors

\begin{tabular}{|c|c|c|c|}
\hline Compound & $\begin{array}{l}\text { 20S proteasome inhibition } \\
\qquad\left(\mathrm{IC}_{50}, \mathrm{nM}\right)^{\mathrm{a}}\end{array}$ & $\begin{array}{l}\text { Live cell proteasome inhibition } \\
\left(\mathrm{IC}_{50}, \mu \mathrm{M}\right)^{\mathbf{b}}\end{array}$ & $\begin{array}{l}\text { JURKAT cell killing } \\
\left(\mathrm{EC}_{50}, \mu \mathrm{M}\right)^{\mathrm{c}}\end{array}$ \\
\hline CEP1612 & 1 & 1 & 0.5 \\
\hline CEP1508 & 5 & 3 & 1.6 \\
\hline CEP1513 & 4 & N.D. & 1.7 \\
\hline CMPD 8 & 22 & 12 & 10 \\
\hline CEP1601 & 300 & $>30$ & $>30$ \\
\hline
\end{tabular}

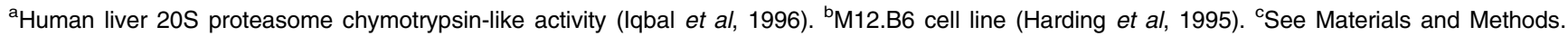
N.D. Not determined
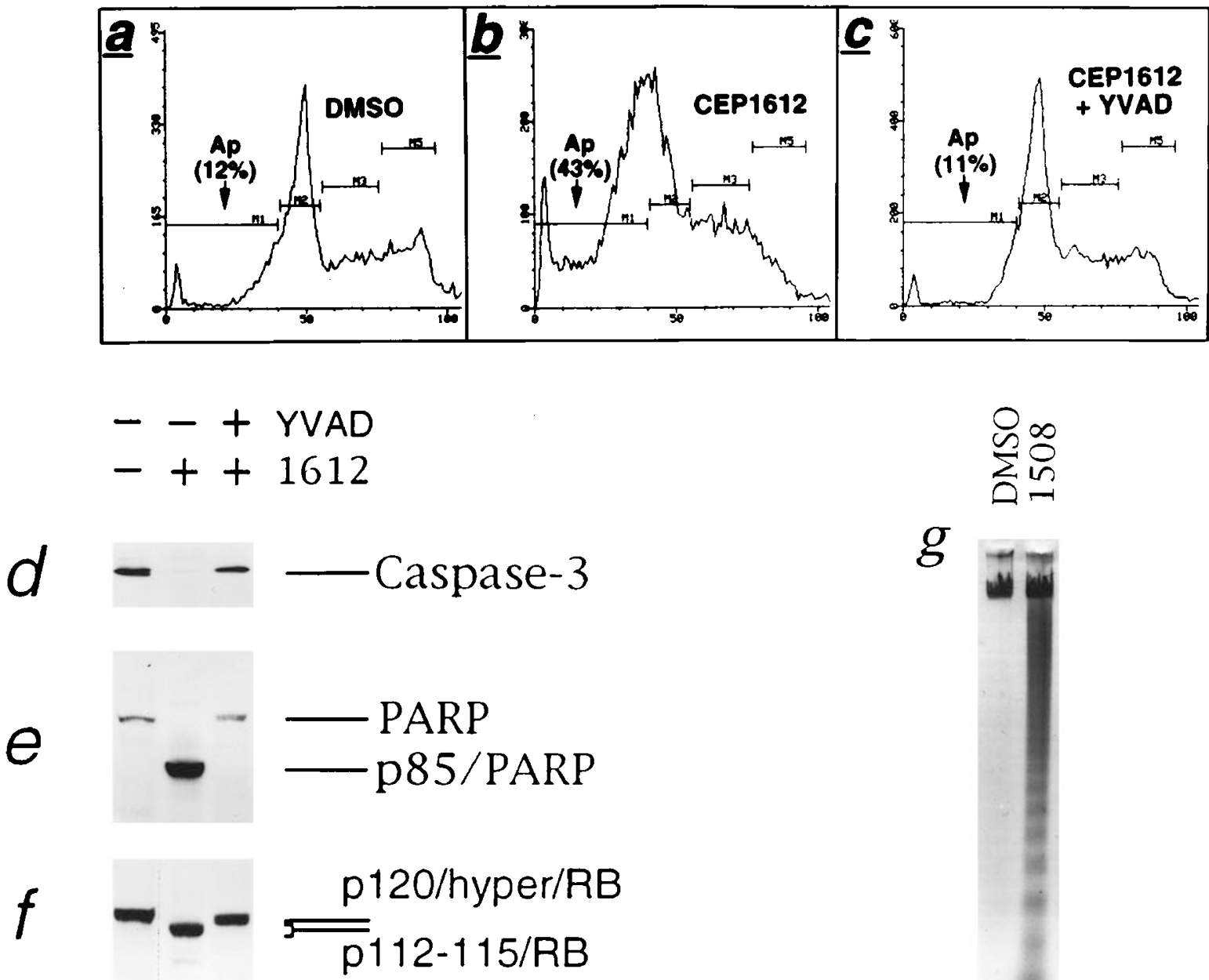

\section{p68/RB}

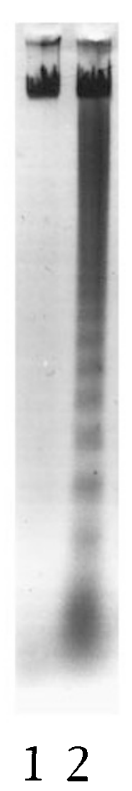

123

Figure 1 Induction of apoptosis by dipeptidyl proteasome inhibitors in human leukemia cells. Exponentially growing human Jurkat T cells were treated with $30 \mu \mathrm{M}$ CEP1612 or an equal percentage $(0.02 \%)$ of DMSO (or -1612$)$ for $4 \mathrm{~h}$, in the absence or presence of YVAD-CMK $(15 \mu \mathrm{M})$ as indicated. Aliquots of cells were prepared. (a-c) Flow cytometry assay. The percentages of the apoptotic population containing sub-G ${ }_{1} D N A$ content (Ap) are indicated). (d-f) Western blot assay. The prepared whole cell extracts were analyzed in ECL-Western blotting using specific antibodies to caspase-3 (d), PARP (e) and RB (f; XZ55). The pro-caspase-3 (Caspase-3), pro-PARP (PARP) and a PARP fragment (p85/PARP) are indicated. Different forms of RB, including the hyperphosphorylated (p120/hyper), a combination of the hypophosphorylated p115 and the C-terminal truncated p112 (p112-115/RB) and an interior cleaved fragment (p68/RB), are also indicated. (g) DNA fragmentation assay. Exponentially growing HL-60 cells were treated with $30 \mu \mathrm{M} \mathrm{CEP} 1508$ or DMSO for $24 \mathrm{~h}$, followed by analysis of the internucleosomal DNA fragmentation using agarose gel electrophoresis 
sin-like activity of the isolated proteasome (Table 1; Harding et al, 1995; lqbal et al, 1996). Moreover, the Jurkat killing potencies of CEP1612, CEP1508, CEP1513, CMPD8 and CEP1601 are essentially identical to their potencies as blockers of the proteasome chymotrypsin-like activity measured in living cells (Table 1; Harding et al, 1995), and are very similar to their potencies as inhibitors of $\mathrm{MHC}$ class I antigen presentation in cells under non-cytotoxic conditions (Harding et al, 1995).

We also compared the apoptosis-inducing abilities of CEP1612, CEP1508 and CMPD8 by measuring sub-G ${ }_{1}$ cell population and changes in PARP and RB proteins in both
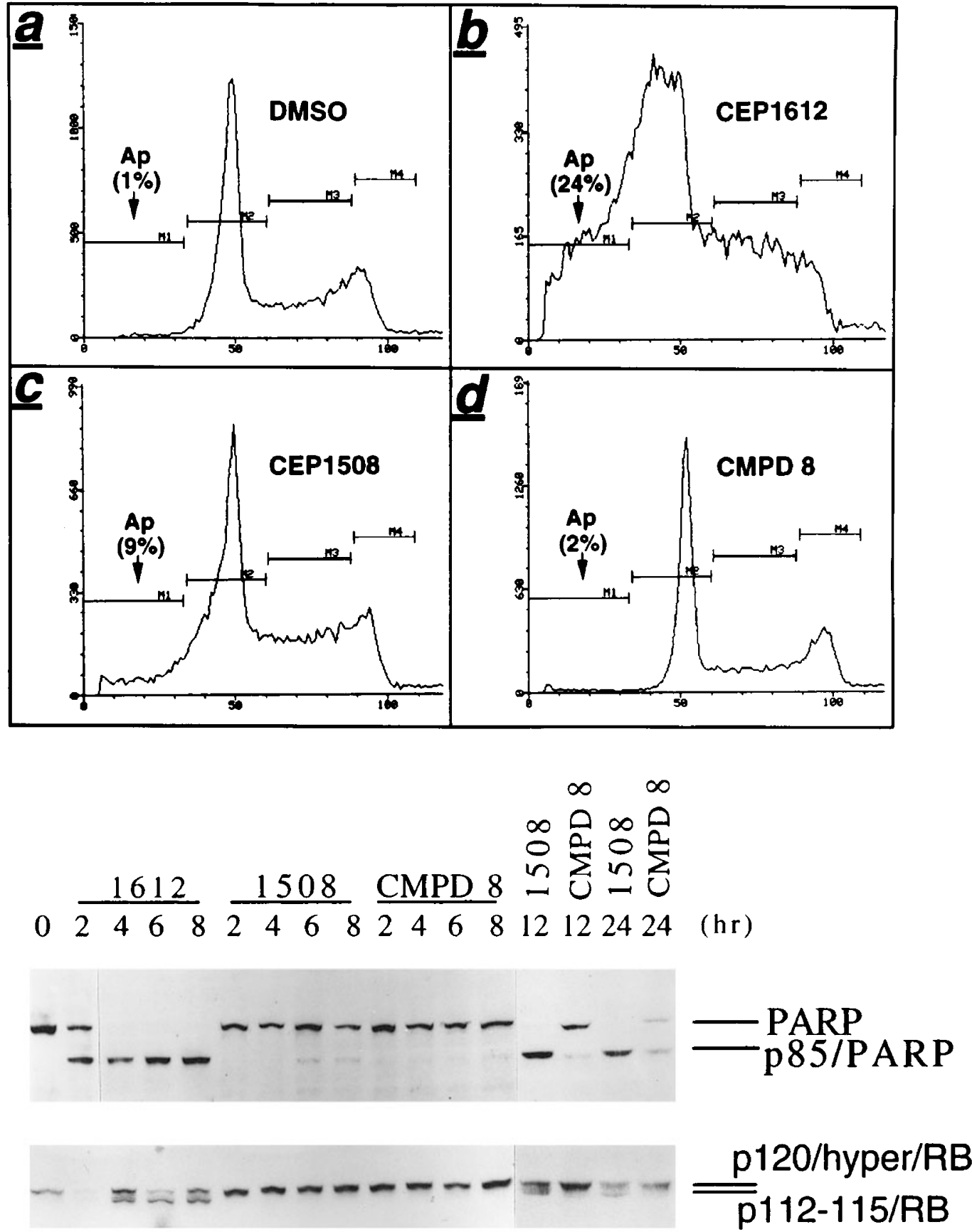

$\begin{array}{llllllllllllllllll}1 & 2 & 3 & 4 & 5 & 6 & 7 & 8 & 9 & 10 & 11 & 12 & 13 & 14 & 15 & 16 & 17\end{array}$

Figure 2 Comparison of the apoptosis-inducing potency of dipeptidyl proteasome inhibitors. Human Jurkat T cells $(0 \mathrm{~h})$ were treated with $15 \mu \mathrm{M}$ CEP1612, CEP1508, CMPD 8 or an equal percentage $(0.01 \%)$ of DMSO for either $8 \mathrm{~h}$, followed by flow cytometry $(\mathbf{a}-\mathbf{d})$, or for the indicated hours, followed by Western blot assay using antibodies to PARP (e) and RB (f; G3-245), as described in the legend of Figure 1. Lane 2 in panel $\mathbf{f}$ was underloaded. Results shown here are representatives of three similar experiments 
kinetics and concentration-response experiments (Figures 2 and 3). When Jurkat $\mathrm{T}$ cells were treated with $15 \mu \mathrm{M}$ CEP1612 for $8 \mathrm{~h}$, there was a $23 \%$ increase in the

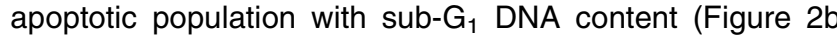
vs a). By comparison, when CEP1508 was used, only an $8 \%$ increase in sub- $\mathrm{G}_{1}$ population was detected (Figure $2 \mathrm{c}$ vs a). Treatment of CMPD8 under the same conditions did not induce apoptosis (Figure 2d). Treatment with $15 \mu \mathrm{M}$

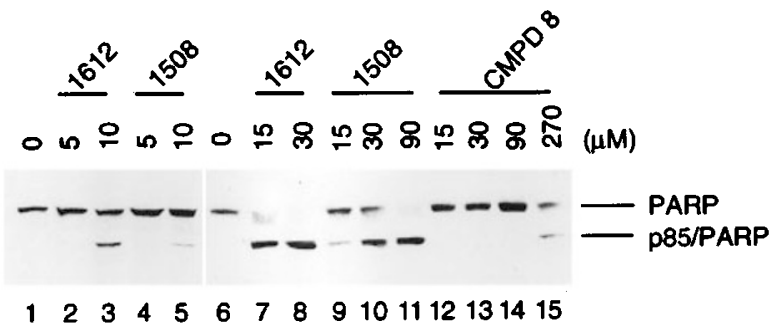

Figure 3 Concentration response of dipeptidyl proteasome inhibitors. Human Jurkat $\mathrm{T}$ cells $(0 \mu \mathrm{M})$ were treated for $6 \mathrm{~h}$ with CEP1612, CEP1508, or CMPD 8 at an indicated concentrtion, followed by Western blot assay using a specific antibody to PARP. Results shown here are representatives of two similar experiments
CEP1612 for $2 \mathrm{~h}$ or longer induced cleavage of PARP and production of $\mathrm{p} 112-115 / \mathrm{RB}$ (Figure $2 \mathrm{e}$ and $\mathrm{f}$, lanes $2-5 \mathrm{vs}$ 1). However, when these cells were exposed to CEP1508, much less p85/PARP and p112-115/RB were found before $8 \mathrm{~h}$ (lanes 6-9 vs lanes 2-5) but their levels were significantly increased after $12 \mathrm{~h}$ or longer of treatment (lanes 14, 16). Less potent than either CEP1612 or CEP1508, $15 \mu \mathrm{M}$ CMPD8 only induced little production of p85/PARP and p112-115/RB after $24 \mathrm{~h}$ treatment (lane 17).

We then treated Jurkat cells for $6 \mathrm{~h}$ with various concentrations of CEP1612, CEP1508 or CMPD8. Again, CEP1612 efficiently induced cleavage of PARP: $30 \%$ at $10 \mu \mathrm{M}, 80 \%$ at $15 \mu \mathrm{M}$, and $100 \%$ at $30 \mu \mathrm{M}$ (Figure 3, lanes 3, 7 and 8). Although less potent than CEP1612, CEP1508 was also able to induce the process of PARP cleavage: $10-15 \%$ at 10 or $15 \mu \mathrm{M}, 75 \%$ at $30 \mu \mathrm{M}$ and $100 \%$ at $90 \mu \mathrm{M}$ (Figure 3, lanes 5, 9-11). In contrast to both CEP1612 and CEP1508, CMPD8 did not induce PARP cleavage when used even up to $90 \mu \mathrm{M}$ (Figure 3, lanes $12-14)$, although it at $270 \mu \mathrm{M}$ caused $35 \%$ of PARP cleaved (lane 15). Therefore, the order of PARP cleavageinducing potencies of these three proteasome inhibitors were CEP1612>CEP1508>CMPD8. When production of p112-115/RB was measured in the same concentration-

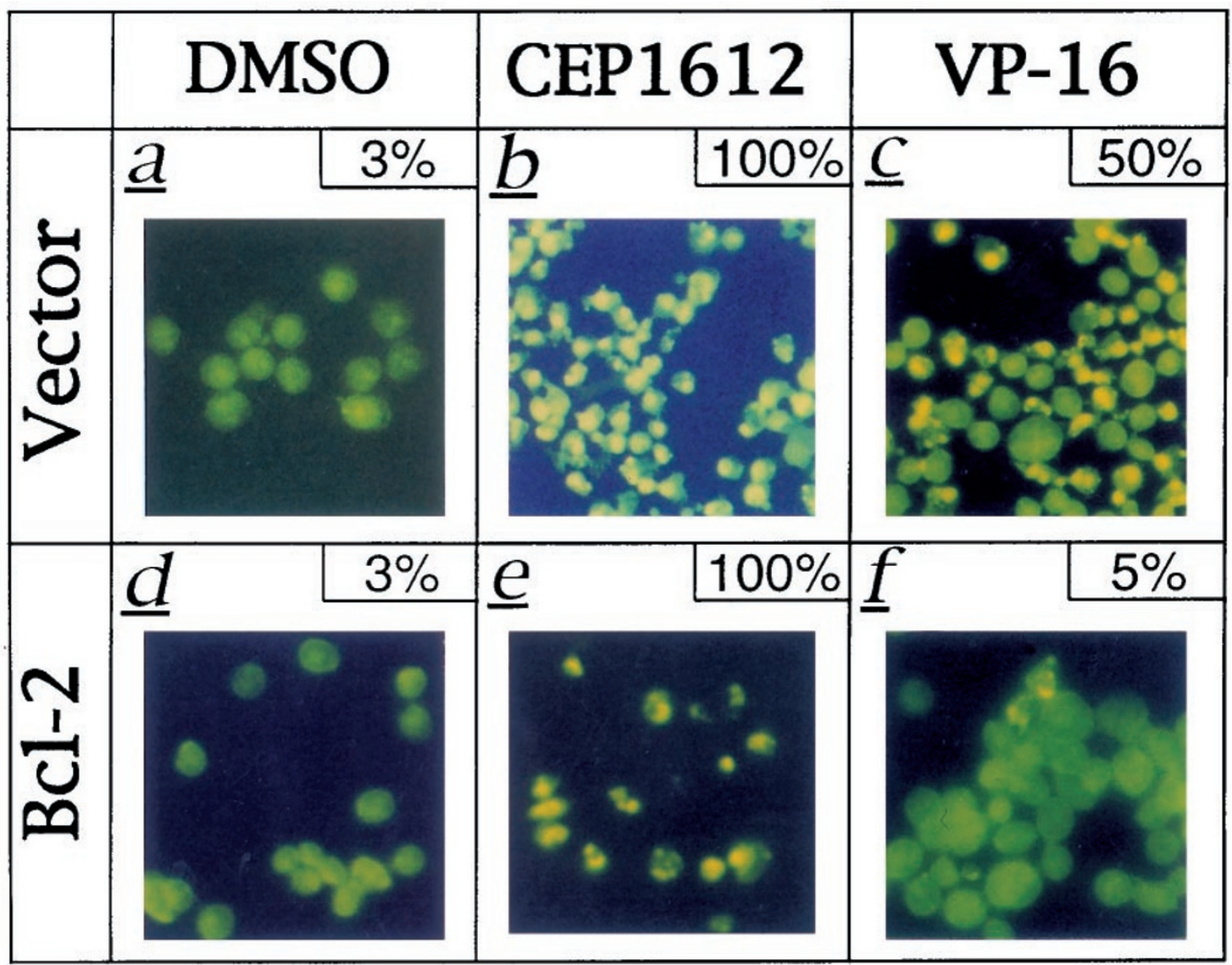

Figure 4 Overexpression of the Bcl-2 oncoprotein fails to inhibit apoptotic nuclear changes induced by $\mathrm{CEP} 1612$. Clonal lines of vector and $\mathrm{Bcl}-2$ were treated with either $30 \mu \mathrm{M}$ CEP1612 for $3.5 \mathrm{~h}(\mathbf{b}, \mathbf{e}), 50 \mu \mathrm{M} \mathrm{VP}-16$ for $8 \mathrm{~h}(\mathbf{c}, \mathbf{f})$ or DMSO for $8 \mathrm{~h}(\mathbf{a}, \mathbf{d})$, following by assaying apoptotic nuclear morphology. The percentage of apoptotic nuclear changes were quantitated and shown at the upper-right corner of each panel. Original magnification: $\times 200$. Similar results were obtained in three independent experiments 
response experiment, the rank order was again CEP1612>CEP1508 > CMPD8 (data not shown). Taken together, the results from both kinetics (Figure 2) and concentration-response (Figure 3) experiments strongly suggest that the order of the apoptosis-inducing potency for these protesome inhibitors was CEP1612> CEP1508>CMPD8. This order again corresponded exactly to that of these three compounds for inhibiting the chymotrypsin-like activity of the isolated proteasome and living cell proteasome, and for blocking MHC class I antigen presentation in cells (Table 1; Harding et al, 1995; Iqbal et al, 1996). Our results indicate that induction of apoptosis by dipeptidyl proteasome inhibitors is probably due to inhibition of the chymotrypsin-like activity of the proteasome.

\section{CEP1612 has greater apoptosis-inducing potency than etoposide and is able to overcome $\mathrm{Bcl}-2$-mediated protection from apoptosis}

It has been shown that overexpression of Bcl-2 oncoprotein inhibits apoptosis in many cell systems (Desoize, 1994; Wang and Reed, 1998). We, therefore, investigated whether Bcl-2 expression in human Jurkat T cells inhibits CEP1612-induced apoptosis. After exposure to $30 \mu \mathrm{M}$ CEP1612 for $3.5 \mathrm{~h}$, $\sim 100 \%$ of the $\mathrm{Bcl}-2-$-overexpressing Jurkat cells (Figure $4 \mathrm{e}$ vs d), similar to the vector-transfected cells (Figure $4 \mathrm{~b} v s$ a), exhibited the apoptosis-specific nuclear morphology. In contrast, expression of $\mathrm{Bcl}-2$ protein blocked the apoptotic nuclear changes induced by etoposide (Figure $4 \mathrm{f} v s \mathrm{c}$ ), as found previously by several groups including ours (Miyashita and Reed, 1993; An et al, 1998). We also noticed that a tratment of $30 \mu \mathrm{M}$ CEP1612 for $3.5 \mathrm{~h}$ killed more Jurkat cells than $50 \mu \mathrm{M}$ etoposide for $8 \mathrm{~h}$ (Figure $4 \mathrm{~b}$ vs $\mathrm{c}$ ), suggesting that the dipeptidyl protesome inhibitor CEP1612 is a more potent apoptosis inducer than the standard chemotherapeutic agent etoposide (also see Figures 6 and 8).

Failure of Bcl-2 to inhibit CEP1612-induced apoptosis (Figure 4) could be due to either the great potency of CEP1612 at the applied concentration, or involvement of a Bcl-2-independent signal transduction pathway(s). To distinguish these two possibilities, the control vector cells were exposed to $15 \mu \mathrm{M}$ CEP1612, a treatment which was less potent than $50 \mu \mathrm{M}$ etoposide. The relative potencieis of CEP1612 and etoposide in this experiment was judged by kinetics of induced PARP cleavage and p112-115/RB production. For example, a treatment of the vector cells with $15 \mu \mathrm{M}$ CEP1612 for $5 \mathrm{~h}$ induced less PARP cleavage and $\mathrm{p} 112-115 / \mathrm{RB}$ production than a treatment with $50 \mu \mathrm{M}$ etoposide for $4 \mathrm{~h}$ (Figure $5 \mathrm{a} v s \mathrm{c}$ and $\mathrm{b} v s \mathrm{~d}$, lane 3). Results from a longer treatment (lanes 4 and 5) also support the notion that $15 \mu \mathrm{M}$ CEP1612 was less potent to the control vector cells than $50 \mu \mathrm{M}$ etoposide. Regardless of this, overexpression of $\mathrm{Bcl}-2$ had much less inhibitory effects on the cells treated with CEP1612 than those with etoposide. Although exposure of Bcl-2expressing cells to CEP1612 for 5-8 h slightly inhibited the process of PARP cleavage and p112-p115/RB production (Figure $5 \mathrm{a}$ and $\mathrm{b}$, lanes 8 and 9 vs 3 and 4), a 10 h-treatment with CEP1612 induced similar levels of PARP cleavage and p112-115/RB production in both $\mathrm{Bcl}-2$-expressing and the vector cells (Figure $5 a$ and $b$, lanes 10 vs 5; compare the ratio of p85/PARP to PARP and that of $\mathrm{p} 112-115 / \mathrm{RB}$ to $\mathrm{p} 120 /$ hyper/RB). By comparison, expression of $\mathrm{Bcl}-2$ almost completely inhibited these PARP and RB changes induced by a treatment of $50 \mu \mathrm{M}$ etoposide for up to 8 (Figure $5 \mathrm{c}$ and $\mathrm{d}$, lanes 7-10 vs 2-5) or even $11 \mathrm{~h}$ (An et al, 1998). It appears, therefore, that the dipeptidyl proteasome inhibitor CEP1612 initiates the apoptotic death program through a Bcl-2-independent pathway.

\section{CEP1612 induces apoptosis in multiple human solid tumor cell lines}

We then investigated whether CEP1612 could induce apoptosis in several human solid tumor lines, which contain either mutant p53 gene and/or overexpressed bcl-2 gene that contribute to their developed drug resistance (Harrison, 1995; Desoize, 1994; Kellen, 1994; Wang and Reed, 1998). Human prostate cancer PC-3 cells were treated with $10 \mu \mathrm{M}$ CEP1612, $10 \mu \mathrm{M}$ etoposide (as a control for apoptosisinducing potency), or an equal percentage of the drug solvent dimethyl sulfoxide (DMSO), followed by separation of the attached and detached cell populations. Both attached and detached cell populations were then used for detection of
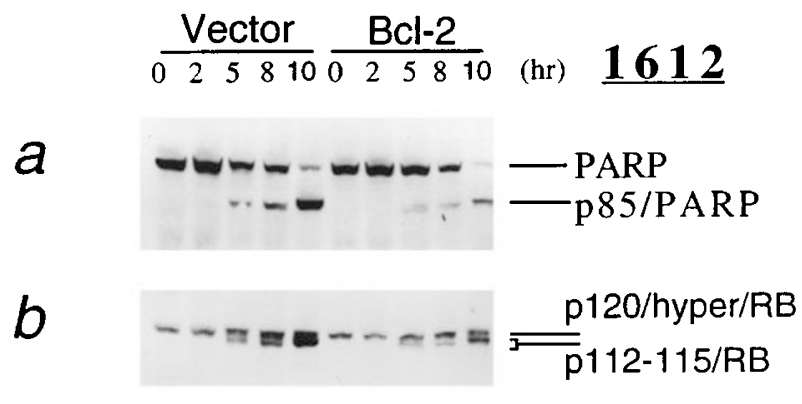

$\begin{array}{llllllllll}1 & 2 & 3 & 4 & 5 & 6 & 7 & 8 & 9 & 10\end{array}$

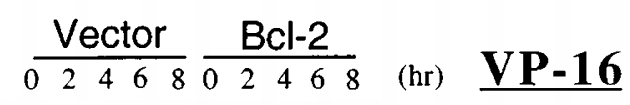

C
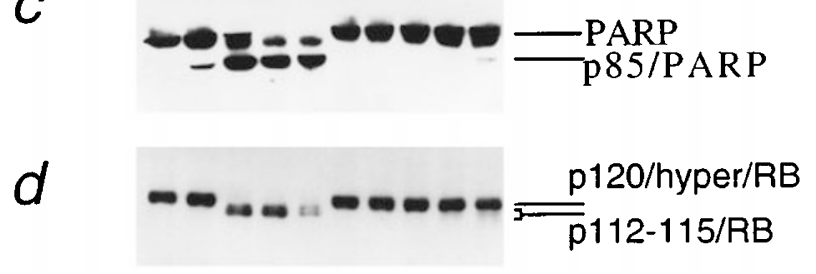

$\begin{array}{llllllllll}1 & 2 & 3 & 4 & 5 & 6 & 7 & 8 & 9 & 10\end{array}$

Figure 5 Overexpression of the $\mathrm{Bcl}-2$ oncoprotein only slightly inhibits cleavage of PARP and production of $\mathrm{p} 112-115 / \mathrm{RB}$ induced by CEP1612. Clonal lines of vector and Bcl-2 were treated with either $15 \mu \mathrm{M} \mathrm{CEP} 1612$ (a, b) or $50 \mu \mathrm{M}$ VP-16 (c, d) for the indicated hours, followed by measurement of changes in PARP (a, c) and RB (b, d; with G3-245 antibody). Results shown here are representatives of at least three similar experiments 
apoptotic nuclear changes. We found that after $36 \mathrm{~h}$ treatment with CEP1612, 50\% of PC-3 cells became detached. All the detached PC-3 cells exhibited typical apoptotic nuclear condensation and fragmentation (Figure 6a). The cellular detachment is probably triggered by induction of apoptosis, because the remaining attached cells also showed apoptotic nuclear morphology (Figure 6b). Little or no detachment was observed in PC-3 cells treated with either etoposide or DMSO; consistent with that, all the remaining attached cells contained normal, round nuclei (Figure 6c, d, respectively).

Similar to PC-3, about half of human prostate cancer DU145 cells became detached after CEP1612 treatment. Almost all the detached and even the attached DU145 cells exhibited apoptosis-specific nuclear morphology (data not shown). The etoposide treatment of these cells only induced very little detachment, and the remaining attached cells still contained normal nuclei (data not shown).

Detachment was also found in at least half of human breast cancer MDA-MB-231 (MDA) and MCF-7 cells, after exposure to CEP1612 for $24 \mathrm{~h}$. Nuclear staining assays demonstrate apoptotic morphology in all of the detached and most of the attached cells (Figure $6 \mathrm{e}, \mathrm{f}, \mathrm{i}$ and $\mathrm{j}$ ). Treatment of these two cell lines with etoposide under the same conditions did not induce apoptosis (Figure $6 \mathrm{~g}, \mathrm{k}$ ). Since MDA-MB-231 cells contain a mutant p53 gene
(Casey et al, 1991) and MCF-7 cells express the wildtype p53 (Bartek et al, 1990), these results further support the idea that induction of apoptosis by CEP1612 is p53independent.

We also found that treatment with $10 \mu \mathrm{M}$ CEP1612, but not etoposide or cisplatin at the same concentration, induced cellular detachment and apoptosis in several other human tumor lines, including oral squamous carcinoma cell line SCC-25, glioblastoma cell line SNB-19 and osteosarcoma cell line U2-OS (data not shown).

We then performed the following kinetics and concentration-response experiments (Figures 7 and 8) and tried to quantitate CEP1612-induced apoptosis in human breast cancer MDA-MB-231 cells. In these experiments, total cell populations, a mixture of both detached and attached cells, were collected after each treatment. Whole cell extracts were then prepared from the cells and used for measurement of PARP cleavage. In the kinetics experiment, the level of CEP1612-induced p85/PARP was detected at as early as $6 \mathrm{~h}(\sim 50 \%)$, which was further increased at $12(\sim 75 \%)$ and $24 \mathrm{~h}$ ( 90\%) (Figure 7a, lanes $3-5$ vs 1, 2 and 6). About half of PARP protein was cleaved into p85/PARP fragment when MDA-MB-231 cells were treated for $17 \mathrm{~h}$ with $10 \mu \mathrm{M}$ CEP1612 (Figure 8a, lane 2). However, neither intact PARP nor p85/PARP were

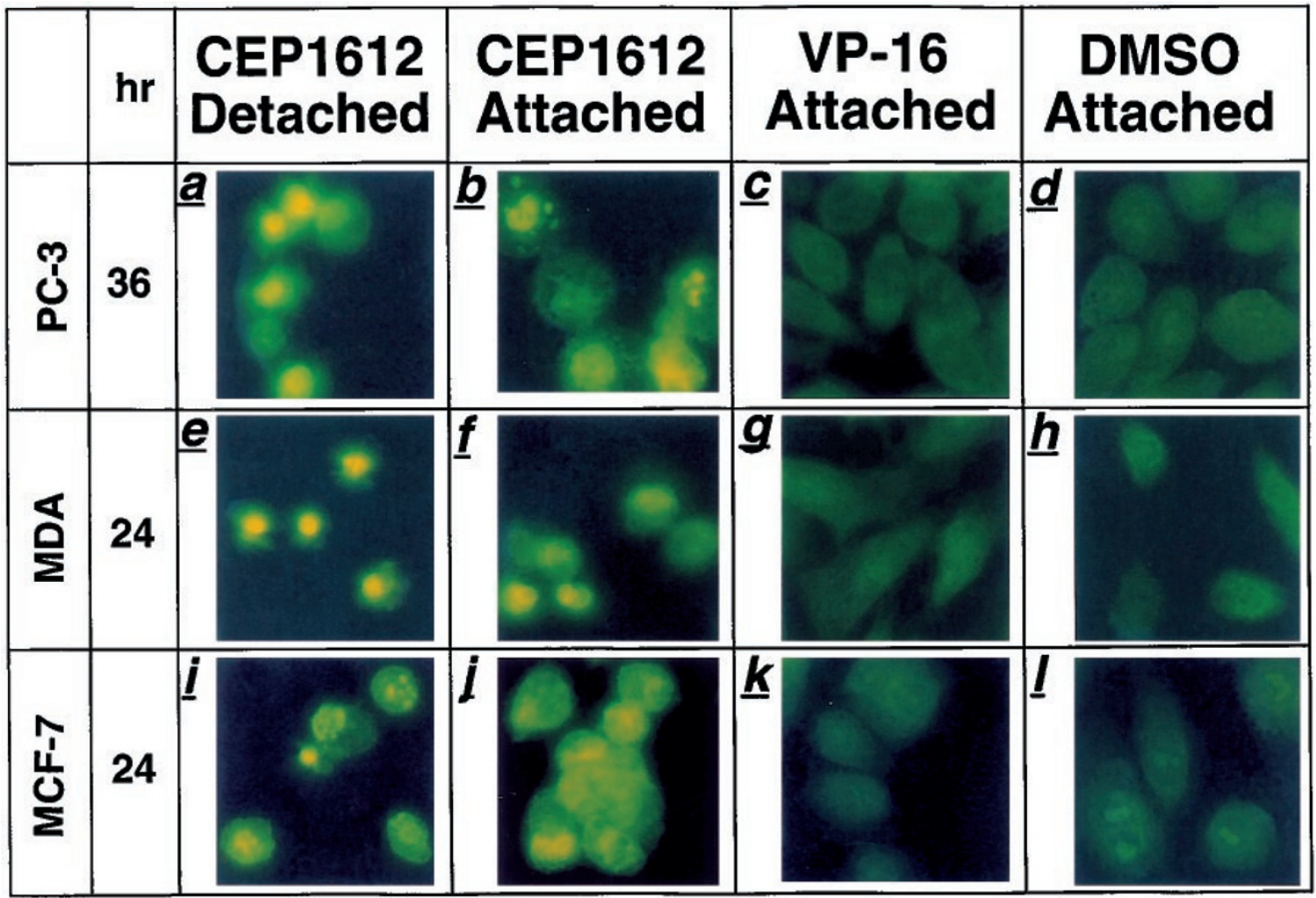

Figure 6 Induction of detachment and apoptosis by CEP1612 in multiple human cancer cell lines. Human cancer cell lines of prostate (PC-3) and breast (MDAMB-231, MCF-7) were treated with $10 \mu \mathrm{M}$ CEP1612, $10 \mu \mathrm{M}$ VP-16, or DMSO for the indicated hours, followed by collecting both detached and attached cell populations. After CEP1612 treatment, $40-60 \%$ of cells of these cancer lines became detached, whereas $<5 \%$ was detached from the treatment with VP-16 or DMSO. Both detached and attached cell populations were used for nuclear staining assay. Original magnification: $\times 200$. Similar results were obtained in two to four independent experiments 
observed in cells treated with $30 \mu \mathrm{M}$ CEP1612; instead, an abundant polypeptide with a faster mobility than p85/ PARP (Figure $8 \mathrm{a}$, lane 3 , indicated by an arrow) was detected by the used, specific PARP antibody. This new band is probably a cleavage product of p85/PARP.

The results presented in Figure 6 had also supported the idea that CEP1612 is a more potent apoptosis inducer than etoposide in all the tested human cancer cell lines (also see Figure 4). To provide additional evidence for this hypothesis, MDA-MB-231 cells were treated with increased concentrations of etoposide, followed by collection of total cell populations and measurement of PARP cleavage. We found that a $17 \mathrm{~h}$-treatment with etoposide at even up to $100 \mu \mathrm{M}$ did not induce the process of PARP cleavage (Figure $8 \mathrm{a}$, lanes 4-6 vs 1), in contrast to effectively induced degradation of PARP by $10 \mu \mathrm{M}$ CEP1612 in the same experiment (lane 2). Taken together, our studies suggest that CEP1612 at a low concentration is able to rapidly induce apoptosis in human solid tumor cells which are known to be resistant to apoptosis induction by the current anticancer drugs.

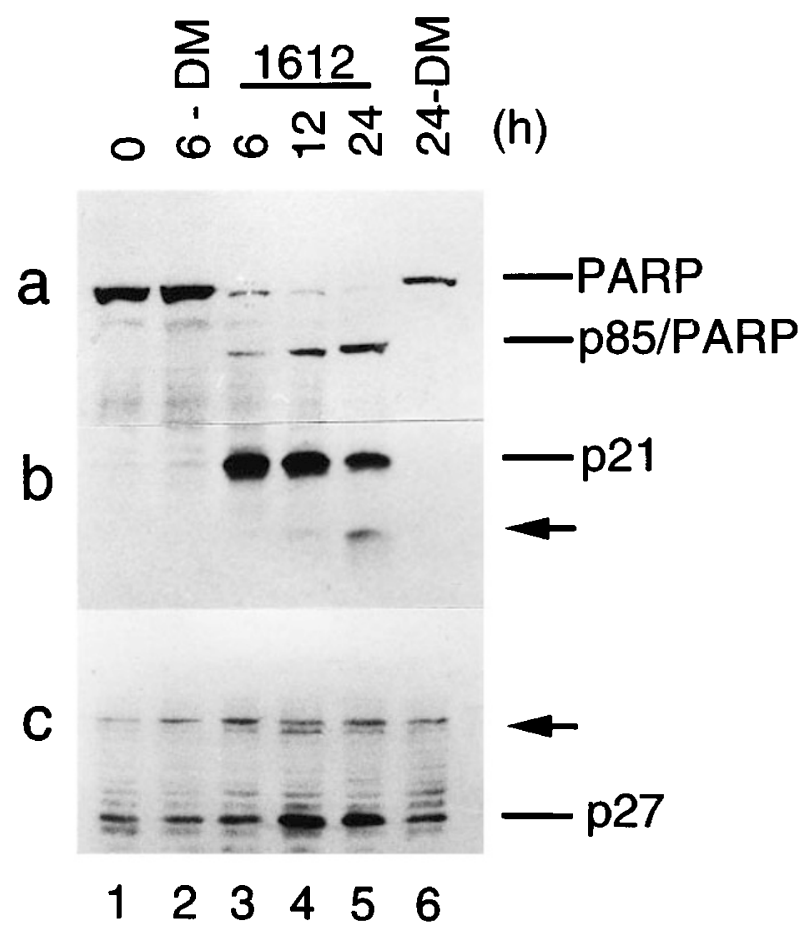

Figure 7 Kinetics of CEP1612-induced apoptosis in MDA-MB-231 cells. Human breast cancer MDA-MB-231 cells $(0 \mathrm{~h})$ were treated with $15 \mu \mathrm{M}$ CEP1612 or an equal percentage $(0.01 \%)$ of DMSO (DM) for the indicated hours, followed by collecting total cell population (a combination of both detached and attached cells) and preparing whole cell extracts. Western blot assay was performed ( $50 \mu \mathrm{g} /$ lane) using a specific antibody to PARP (a), p21 (b) or p27 (c). The pro-PARP (PARP) and a PARP fragment (p85/PARP) are indicated. The $\mathrm{p} 21$, a putative $\mathrm{p} 21$ fragment ( $\mathrm{p} 14$, pointed by an arrow in $\mathrm{b}$ ), p27 and a putative ubiquitinated p27-containing protein (p70, pointed by an arrow in c) are also indicated. Results shown here are representatives of three similar experiments

\section{CEP1612 induces apoptosis selectively in SV40-transformed, but not in the parental normal, human fibroblasts}

We then investigated whether CEP1612 has any selectivity in induction of apoptosis between transformed and normal cells. To do that, we used a normal human fibroblast cell line (WI-38) and its SV40-transformed derivative (WI-38 VA13). This pair of cell lines was treated with either $10 \mu \mathrm{M}$ CEP1612, $10 \mu \mathrm{M}$ etoposide or DMSO for up to $22 \mathrm{~h}$, followed by separation of the attached and detached cell populations. We found that the CEP1612 treatment induced a detachment in the majority of SV40-transformed cells; all of the detached, and most of the attached, transformed cells exhibited apoptotic nuclear changes (Figure 9a, b vs d). In contrast, exposure of normal WI-38 cells to CEP1612 did not induce either detachment or apoptotic nuclear morphology, although this treatment caused enlargement of the cells (Figure 9e vs g), which was probably due to a growth arrest in $\mathrm{G}_{1}$ phase of the cell cycle (Hinds et al, 1992; also see Figure 10b). Treatment with etoposide did not induce

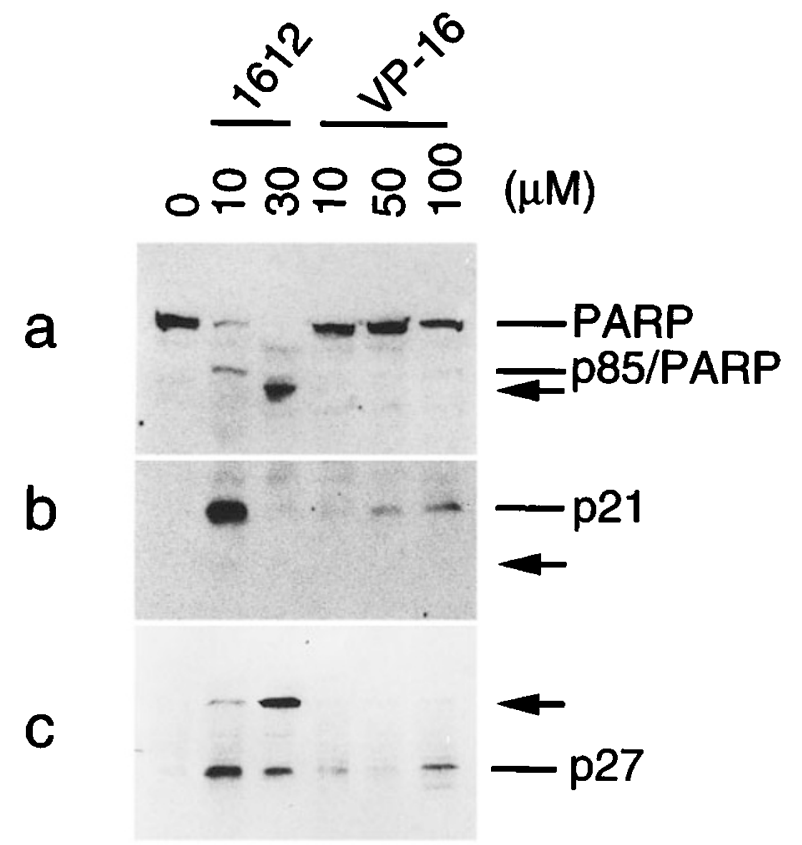

123456

Figure 8 Concentration response of CEP1612 and etoposide in human breast cancer MDA-MB-231 cells. MDA-MB-231 cells $(0 \mu \mathrm{M})$ were treated for $17 \mathrm{~h}$ with CEP1612 or VP-16 at an indicated concentration, followed by collection of total cell population and performance of Western blot assay (50 $\mu \mathrm{g} /$ lane) using a specific antibody to PARP (a), p21 (b) or p27 (c). The proPARP (PARP), a PARP fragment (p85/PARP), a putative p85/PARP cleavage fragment (indicated by an arrow in a), p21, a putative p21 fragment ( $p 14$, indicated by an arrow in b), p27 and a putative ubiquitinated p27-containing protein ( $p 70$, indicated by an arrow in c) are shown. Similar results were obtained in at least two independent experiments 
apoptosis in either transformed or normal WI-38 cells (Figure $9 \mathrm{c} v s \mathrm{~d}$ and $\mathrm{f} v s \mathrm{~g}$ ).

In a parallel comparison experiment, a mixture of both detached and attached cells of each line was collected after treatment with CEP1612, etoposide of DMSO, followed by measurement of PARP cleavage. Consistent with the results from nuclear staining assay (Figure 9), CEP1612-induced PARP cleavage was observed only in the transformed (Figure 10a, lanes 6 vs 4), but not in the normal (lanes 3 vs 1), WI-38 cells. The etoposide treatment did not induce PARP cleavage in either of these cell lines (Figure 10a). We also noticed a $\sim$ fourfold increase in the basal level of PARP protein expression in the transformed cells (Figure 10a, lanes 4 vs 1; note: fourfold more protein from WI-38 cells was used). Taken together, our data suggest that CEP1612 selectively induces the apoptotic death process in the SV40transformed human fibroblasts.

\section{Involvement of cyclin-dependent kinase inhibitors p21 and p27 in the process of CEP1612-induced apoptosis}

Recent studies from several laboratories have suggested that dysregulation of cell cycle progression may be involved in the initiation of apoptosis (Lee et al, 1993; Dou et al, 1995; Linette et al, 1996; Dou, 1997). In addition, it has been reported that the ubiquitin-proteasome pathway plays an essential role in the regulation of several important cell cycle proteins, including the cyclin-dependent kinase inhibitors p21 (Blagosklonny et al, 1996) and p27 (Pagano et al, 1995). We hypothesized that inhibition of proteasome may lead to an 'abnormal' accumulation (i.e., up to, or above, a critical threshold) of p21 and/or p27, which might be able to crosstalk to some apoptosis initiator(s), triggering cellular suicide. To provide evidence for this hypothesis, we determined levels of p21 and p27 during the process of apoptosis induced by dipeptidyl proteasome inhibitors. Treatment of human breast cancer MDA-MB-231 cells with $15 \mu \mathrm{M}$ CEP1612 for as early as $6 \mathrm{~h}$ increased the level of p21 protein by 45-fold (Figure 7b, lanes 3 vs 1 and 2), which occurred at the initiation of PARP cleavage (compare to Figure 7a). After $12 \mathrm{~h}$ treatment, the level of p21 protein still remained high, but a faint band of $\sim 14 \mathrm{kDa}$ started to be detected (Figure 7b, lane 4, indicated by an arrow). At $24 \mathrm{~h}$, the p21 level was decreased, accompanied by an increase in the level of p14 (Figure 7b, lane 5). It appears that p21 is cleaved into p14 during apoptosis. A band of $\sim 45 \mathrm{kDa}$ was also detected in MDAMB-231 cells after CEP1612 treatment (data not shown), which may contain ubiquitinated p21 (see Discussion).

A $6 \mathrm{~h}$ treatment with CEP1612 also slightly increased the p27 level, which was further increased after 12 and $24 \mathrm{~h}$ treatment (3-4-fold; Figure 7c, lanes 3-5 vs 1, 2 and $6)$. In addition, a band of $\sim 70 \mathrm{kDa}$ appeared at as early as $6 \mathrm{~h}$, peaked at $12 \mathrm{~h}$, and then decreased at $24 \mathrm{~h}$ (Figure 7c, lanes 3-5, indicated by an arrow). The p70 may contain ubiquitinated p27 since a similar p70 containing ubiquitinated p27 was found in LLnL-treated human osteosarcoma MG-63 cells (Pagano et al, 1995). No such changes in the levels of p21 and p27 were found in MDAMB-231 cells treated with DMSO (Figure 7). These results suggest that inhibition of proteasome by CEP1612 leads to

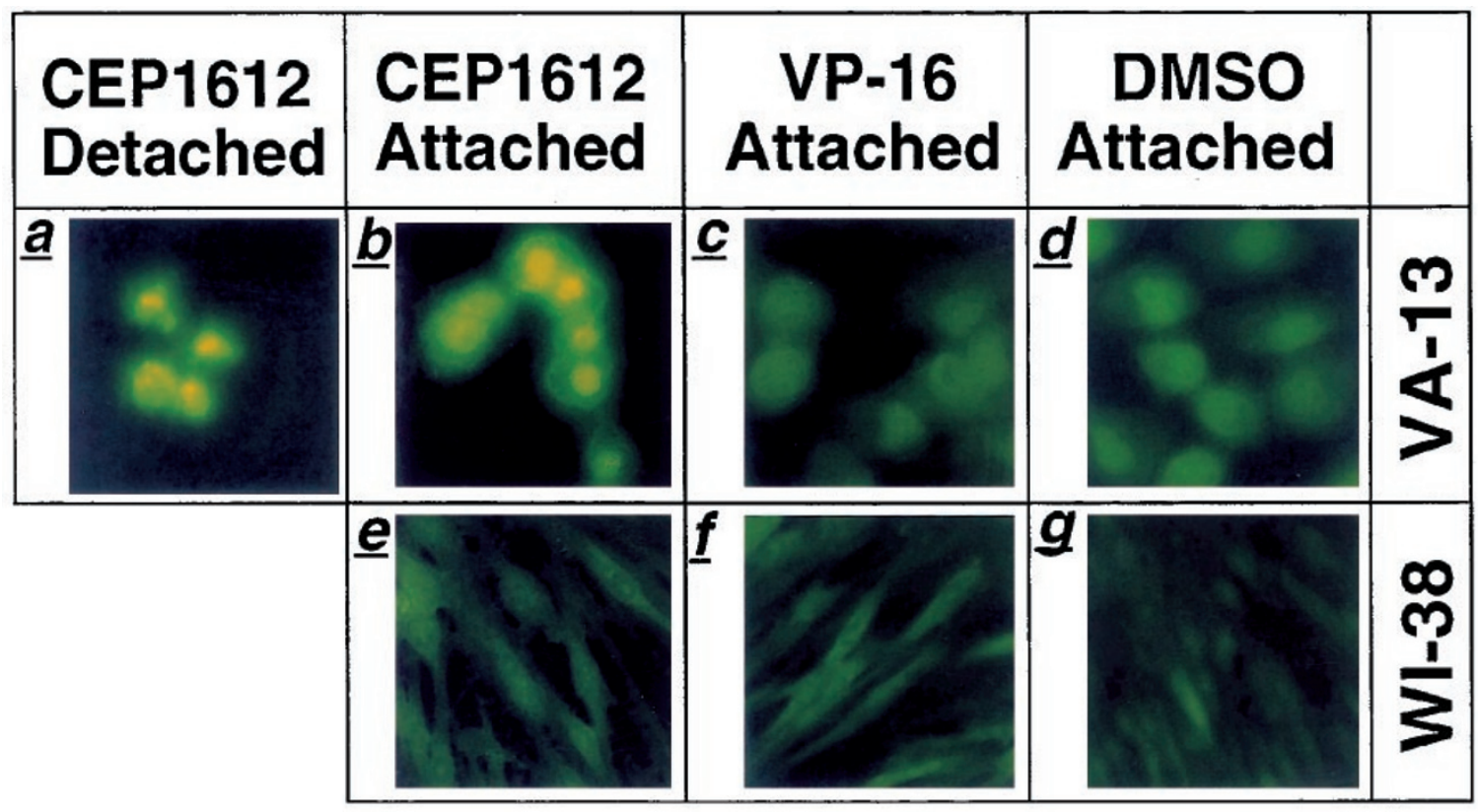

Figure 9 CEP1612 selectively induces apoptotic nuclear changes in SV40-transformed, but not the parental normal, human fibroblasts. The normal (WI-38) and SV40-transformed (VA-13) human fibroblasts were treated with $10 \mu \mathrm{M}$ CEP1612, VP-16 or DMSO for $22 \mathrm{~h}$, followed by separately collecting detached and attached cell populations. After CEP1612 treatment, 50\% of transformed, but not normal, human fibroblasts became detached, whereas the VP-16 treatment induced $<5 \%$ of cells detached in each of these lines. Both detached and attached cell populations were used for nuclear staining assay. Original magnification: $\times 200$. Results shown here are representatives of five similar experiments 
sequential accumulation of $\mathrm{p} 21$ and $\mathrm{p} 27$ during the process of apoptosis.

We next determined changes in the levels of p21 and p27 in the CEP1612-concentration-response experiment. When MDA-MB-231 cells were treated for $17 \mathrm{~h}$ with $10 \mu \mathrm{M}$ CEP1612, the p21 level was 75-fold higher than that of the untreated cells (Figure 8b, lanes 2 vs 1). At the same time, a p14 band was also detected on a longer exposed X-ray film (data not shown). When $30 \mu \mathrm{M}$ CEP 1612 was used, neither p21 nor p14 were detected (Figure 8b, lane 3), suggesting that in the late stage of apoptosis, p14 is not accumulated and could be further cleaved. In cells treated

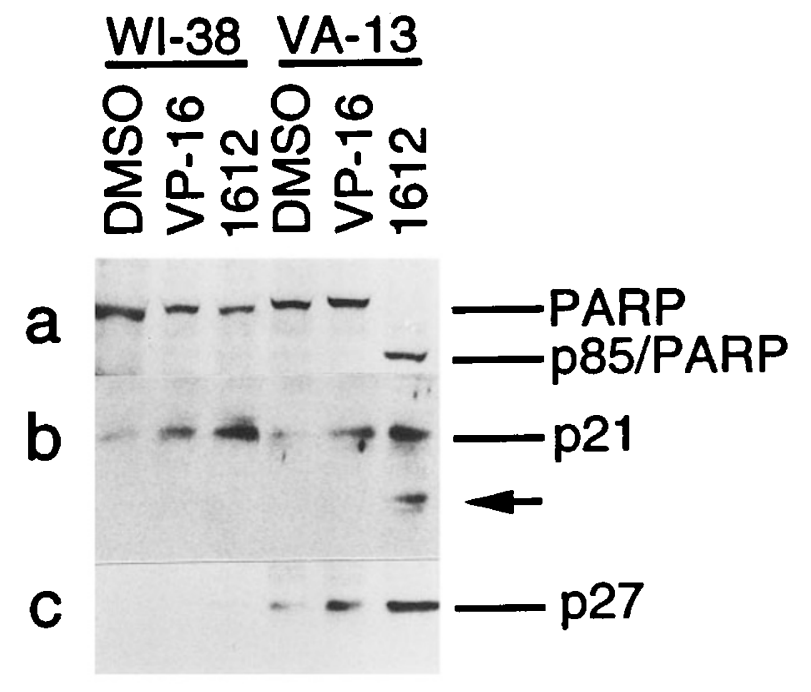

123456

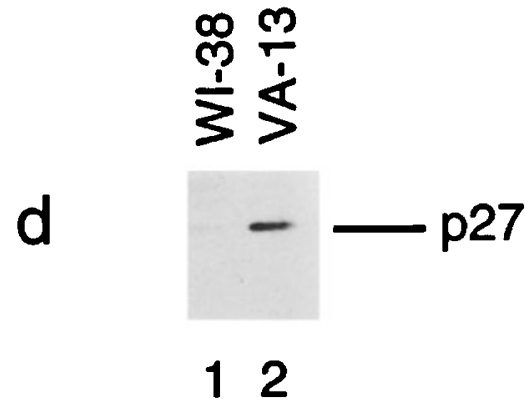

Figure 10 Comparison of proteasome inhibitor effects between normal and SV40-transformed human fibroblasts. (a-c) Normal (WI-38) and SV40transformed (VA-13) human fibroblasts were treated with $10 \mu \mathrm{M}$ CEP1612, VP. 16 or DMSO for $22 \mathrm{~h}$, followed by collecting total cell population and preparing whole cell extracts. Western blot assay was performed using a specific antibody to PARP (a), p21 (b) or p27 (c). In (a), each lane contains either $80 \mu \mathrm{g}$ protein from WI-38 cells or $20 \mu \mathrm{g}$ protein from Wi-38 VA13 cells. In (b) and (c), each lane contains $50 \mu \mathrm{g}$ protein from either WI-38 or WI-38 VA13 cells. (d) Normal and SV40-transformed WI-38 cells were treated with $50 \mu \mathrm{M} \mathrm{LLnV} \mathrm{for}$ $22 \mathrm{~h}$, followed by Western blot assay ( $50 \mu \mathrm{g}$ protein per lane) using a specific antibody to $p 27$. The PARP, p85/PARP, p21, a putative p21 fragment ( $p 14$, pointed by an arrow in $\mathbf{b}$ ), and p27 are indicated. Similar results were obtained in at least three independent experiments with $10 \mu \mathrm{M}$ CEP1612, the p27 level was increased by 15fold, and a p70 band was also detected (Figure 8c, lanes 2 vs 1). When the CEP1612 concentration was increased to $30 \mu \mathrm{M}$, the level of p27 was decreased while that of p70 dramatically increased, $\sim 40$-fold higher than the level of the untreated cells (Figure $8 c$, lanes 3 vs 2). This data further supports the notions that $p 70$ contains ubiquitinated p27 and that CEP1612 acts via proteasome inhibition. These changes in p21 and p27 were also associated with induction of apoptosis (compare to Figure 8a).

We had also shown that MDA-MB-231 cells were relatively resistant to etoposide-induced apoptosis (Figures $6 \mathrm{~g}$ and $8 \mathrm{a}$ ). To investigate whether failure of these cells to initiate apoptotic death program is associated with their failure to accumulate p21 and/or p27, we measured the levels of these cyclin-dependent kinase inhibitors in the same etoposide-concentration-response experiment. We found that etoposide, when used at even up to $100 \mu \mathrm{M}$, was unable to effectively accumulate either p21 or p27 protein: $\leqslant$ fourfold for p21 and $\leqslant$ twofold for p27 (Figure 8b and $c$, lanes 4-6 vs 1). In addition, neither p14 (the putative p21 cleavage fragment) nor p70 (the putative ubiquitinated p27) were detected in etoposide-treated cells (Figure $8 \mathrm{~b}$ and $\mathrm{c}$ ). Therefore, it seems that apoptosis is associated with accumulation of p21 and/or p27 protein up to, or above, a critical threshold level (see Discussion).

We then investigated whether accumulation of p21 and/ or p27 is involved in the selective killing activity of CEP1612 on the SV40-transformed vs normal human WI38 fibroblast cells (Figures 9 and 10a). The CEP1612 treatment increased the level of p21 by 9-10-fold in both the transformed and normal WI-38 cells (Figure 10b, lanes 6 vs 4 and 3 vs 1). However, the p14 band, detectable by the p21 antibody, was only observed in CEP1612-treated transformed cells (Figure 10b, lane 6, indicated by an arrow). Less potent than CEP1612, etoposide only increased the p21 level by $\sim$ threefold in both transformed and normal cells (Figure 10b, lanes 2 vs 1 and 5 vs 4). Since apoptosis was only found in CEP1612-treated transformed cells (Figures 9 and 10a), these results suggest that a significant accumulation of p21 protein, if necessary, is not sufficient for the initiation of apoptosis.

We noticed that the basal level of p27 in the transformed cells was higher than that of normal WI-38 cells (Figure $10 \mathrm{c}$, lanes 4 vs 1 ; note: the same amount of protein was used from both cell lines). The p27 level in the transformed cells was increased by eightfold after CEP1612 treatment (Figure 10c, lanes 6 vs 4). The p27 was also increased slightly in normal WI-38 cells after CEP1612 treatment (Figure 10c, lanes 3 vs 1). The etoposide treatment increased the p27 level moderately (2.5-fold) in the transformed cells, but had no detectable effects in normal WI-38 cells (Figure 10c, lanes 5 and 2). To study whether other proteasome inhibitors also have a similar selective action on p27 and apoptosis, both the SV40-transformed and normal WI-38 cells were treated with the tripeptidyl proteasome inhibitor LLnV, followed by measurement of p27 accumulation and PARP cleavage. We found that the level of p27 in the transformed cells was tenfold higher than that in the normal cells after LLnV treatment (Figure 10d, 
lanes 2 vs 1). Consistent with that, much more PARP protein was cleaved in the transformed than in the normal WI-38 cells (data not shown). This data strongly suggests that a proteasome inhibitor, such as CEP1612, accumulates p27 expression up to, or above, a critical threshold level, which is accompanied by a selective initiation of apoptotic death program on the transformed vs normal human fibroblasts.

\section{Discussion}

We investigated the potential role of the proteasome in the process of apoptosis by using novel and selective dipeptidyl inhibitors (lqbal et al, 1995, 1996; Harding et al, 1995). We found that CEP1612 rapidly induced apoptosis in p53-mutant human Jurkat $\mathrm{T}$ and HL-60 cells, as evidenced by appearance of the apoptotic population with sub-G ${ }_{1}$ DNA content, nuclear condensation and fragmentation, the internucleosomal DNA fragmentation, process and activation of caspase-3, cleavage of PARP, and dephosphorylation and cleavage of RB (Figure 1). Addition of YVAD-CMK blocked all of the above apoptotic events (Figure 1), confirming the requirement of caspase activation in proteasome inhibitorinduced, p53-independent apoptosis. The rank order potency for induction of apoptosis by these dipeptidyl proteasome inhibitors (Table 1 and Figures 2 and 3 ) matches precisely the order for inhibition of the chymotrypsin-like activity of the isolated proteasome (Harding et al, 1995; lqbal et al, 1996), blockade of the proteasome chymotrypsin-like activity measured in living cells (Harding et al, 1995), and inhibition of MHC class I antigen presentation in cells under non-cytotoxic conditions (Harding et al, 1995). Our findings by using dipeptidyl proteasome inhibitors are consistent with, and have further extended, the most recent reports from other laboratories in which apoptotic death was induced by different proteasome inhibitors including lactacystin and tripeptide aldehydes (Imajoh-Ohmi et al, 1995; Shinohra et al, 1996; Drexler, 1997; Lopes et al, 1997; Tanimoto et al, 1997). Furthermore, our findings have also confirmed most recent reports that the apoptosis-inducing abilities of tripeptide proteasome inhibitors are similar to their inhibitory potencies toward the chymotrypsin-like activity of the proteasome (Lopes et al, 1997; Tanimoto et al, 1997).

In addition, we have reported several novel findings. First, CEP1612 has a greater apoptosis-inducing potency than the standard chemotherapeutic drug, etoposide. Consistent with this was the finding that CEP1612, but not etoposide, was able to induce apoptosis in Jurkat cells overexpressing $\mathrm{Bcl}-2$ and in multiple human cancer cell lines of prostate, breast, tongue and brain (Figures 4-8 and data not shown). Secondly, CEP1612 induces apoptosis selectively in the SV40-transformed, but not in the parental normal, human fibroblasts (Figures 9 and 10). Finally, during CEP1612-induced apoptosis, the levels of the cyclin-dependent kinase inhibitors p21 and p27 were accumulated sequentially, and a selective induction of p27 by CEP1612 on the transformed vs normal human fibroblasts is tightly associated with the selective tumorkilling activity of this proteasome inhibitor (Figures 7-10).

The 26S proteasome complex has at least five distinct proteolytic activities, including a chymotrypsin-like component (Wasserman et al, 1994; Rivett, 1993). However, it is still not very clear which activity of the proteasome is affected by proteasome inhibitors that leads to induction of apoptosis. Our results reported here have suggested that tumor cell survival may require the proteasome chymotrypsin-like activity. We found that the rank in ability to induce apoptosis by the dipeptidyl proteasome inhibitors in Jurkat $T$ cells (Table 1 and Figures 2 and 3) corresponded to their rank in potency toward inhibition of the chymotryptic activity of the isolated proteasome and living cell proteasome (lqbal et al, 1995, 1996; Harding et al, 1995). In addition, CEP1612 (Ki $<2 \mathrm{nM}$; lqbal et al, 1995) is a more potent inhibitor than the tripeptide aldehydes (i.e. LLnV's Ki=21 nM; Rock et al, 1994) toward the proteasome chymotrypsin-like activity. Consistent with this, CEP1612 has a greater apoptosis-inducing ability than tripeptide aldehydes. For example, we observed that a treatment of human Jurkat cells or HL-60 cells with $30 \mu \mathrm{M}$ CEP1612 for $3-4 \mathrm{~h}$ was sufficient to induce a complete cleavage of PARP (Figure 1e; data not shown). In contrast, treatment of these cells with $50 \mu \mathrm{M}$ LLnV for $6 \mathrm{~h}$ only induced $\sim 50 \%$ PARP cleavage (data not shown; Drexler, 1997). Very recently, two other groups also reported that the apoptosisinducing abilities of tripeptide proteasome inhibitors were also similar to their inhibitory potencies toward the chymotrypsin-like activity (Lopes et al, 1997; Tanimoto et al, 1997). Taken together, results from different groups including ours suggest that the proteasome chymothypsinlike activity is involved in the cellular survival pathways and that inhibition of this activity leads to induction of apoptosis.

To our knowledge, CEP1612 is probably the most potent aldehyde-based inhibitor of the chymotrypsin-like activity of the proteasome characterized so far $(K i<2 \mathrm{nM}$; Iqbal et al, 1995). Consistent with this, CEP1612 is also a very potent apoptosis inducer in all the tested human cancer cell lines, most of which are largely resistant to apoptosis induction by the current standard chemotherapy (Harrison, 1995; Desoize, 1994; Kellen, 1994; Wang and Reed, 1998; Figures 6 and 8). Indeed, when used in human Jurkat cells, a lower concentration of CEP1612 at an earlier time point was more potent than a higher concentration of etoposide at a later time point (Figure 4). Furthermore, when used in human breast cancer MDAMB-231 cells that are relatively resistant to chemotherapeutic agents, a lower concentration of CEP1612 was again more potent than a higher concentration of etoposide in induction of apoptosis (Figure 8a). Finally, most of the other human solid tumor cells are also resistant to apoptosis induction by standard anticancer drugs (Harrison, 1995; Desoize, 1994; Kellen, 1994; Wang and Reed, 1998). However, a low concentration of CEP1612 again rapidly activated the apoptotic death pathway in all the tested human cancer cell lines of prostate, tongue and brain (Figure 6 and data not shown). In contrast, the same concentration of etoposide or cisplatin failed to induce apoptosis in these cancer cells (Figure 6 and data not 
shown). Therefore, at least in the tested cell lines, CEP1612 is a much more potent apoptosis inducer than etoposide. Whether CEP1612 possesses a greater potency than etoposide to repress tumor growth in vivo remains to be determined.

We also found that CEP1612, but not etoposide, was able to induce apoptosis in Jurkat $\mathrm{T}$ cells overexpressing Bcl-2 (Figures 4 and 5). This was also true even when a lower concentration of CEP1612 was compared to a higher concentration of etoposide (Figure 5; An et al, 1998). Our data are consistent with the hypothesis that CEP1612 induces apoptosis through a novel, Bcl-2-independent pathway. In addition, dipeptidyl proteasome inhibitorinduce apoptosis is also p53-independent, which is different from proteasome-mediated p53-dependent apoptosis reported most recently (Shinohara et al, 1996; Lopes et al, 1997). These properties make the dipeptidyl proteasome inhibitors a novel potential anticancer agent for the treatment of human cancers, especially those overexpressing Bcl-2 and/or lacking p53.

It has been suggested that improper activation and aberrant cell cycle progression can initiate cellular apoptosis (Lee et al, 1993; Dou et al, 1995; Linette et al, 1996; Dou, 1997). It has also been reported that abundance of the cyclin-dependent kinase inhibitors p21 and p27 can be regulated through the ubiquitin-proteasome pathway (Blagosklonny et al, 1996; Pagano et al, 1995). We hypothesized that an 'abnormal' accumulation of p21 and/or p27 up to, or above, a critical threshold might be sufficient to deregulate the cell cycle progression, leading to activation of some apoptosis initiator(s) and induction of apoptosis. Consistent with this hypothesis, at an early stage of apoptosis in human breast cancer MDA-MB-231 cells treated with CEP1612, the level of p21 was significantly increased (45-75-fold), which was followed by accumulation of p27 (3-15-fold) (Figures 7 and 8 ). In contrast to CEP1612, etoposide treatment neither significantly increase the p21 or p27 levels nor induce apoptosis (Figure 8), further supporting the correlation between accumulation of p21 and/or p27 and induction of apoptosis. How abnormally accumulated p21 and/or p27 are involved in triggering the apoptotic death process remains to be determined.

The accumulation of p21 and p27 (Figures 7 and 8) was due to inhibition of proteasome by CEP1612, which is supported by the following evidence. First, as discussed above, CEP1612 is a specific, potent proteasome inhibitor. Secondly, after CEP1612 treatment, a p45 and a p70 were detected by the p21 and p27 antibodies, respectively (Figures 7 and 8 and data not shown), which may contain ubiquitinated p21 or p27, respectively. Consistent with this, the decrease in the level of p27 was accompanied by an increase in that of p70 (Figure 8). Finally, our findings are consistent with some previous reports from other laboratories. For example, accumulation of p27 was also observed in HL-60 cells after treatment with LLnV (Drexler, 1997). In addition, a similar p70 that contain ubiquitinated p27 was found in LLnL-treated human osteosarcoma MG-63 cells (Pagano et al, 1995).
We found that the CEP1612 treatment induced detachment and apoptosis preferably in SV40-transformed cells (Figure 9). Consistent with this, the CEP1612 treatment induced cleavage of PARP only in the transformed, but not in the normal, WI-38 cells (Figure 10a). Towards the goal of eventually understanding how proteasome inhibitors selectively act on the transformed cells, we measured changes in the levels of p21 and p27 in both the transformed and normal WI-38 cells after treatment with CEP1612, etoposide or DMSO, and compared these changes to sensitivity of both cell lines to induction of apoptosis (Figures 9 and 10). We found that CEP1612 treatment significantly increased p21 level $(9-10$-fold) in both the transformed and normal WI-38 cells (Figure 10b). Since apoptosis was only found in the transformed cells (Figures 9 and 10a), this data suggests that accumulation of p21 is probably necessary, but not sufficient, for induction of apoptosis. The CEP1612-induced p21 in normal WI-38 cells is probably involved in growth arrest in $G_{1}$ phase since these cells were enlarged after treatment (Figure 9), a phenotype of $G_{1}$ cells reported previously (Hinds et al, 1992). Treatment of both transformed and normal WI-38 cells with etoposide only slightly increased the p21 level, but did not induce apoptosis (Figures 9 and 10), further supporting the notion that if p21 accumulation is involved in induction of apoptosis, its level must be induced up to, or above, a critical threshold. Interestingly, when SV40transformed WI-38 cells were exposed to CEP1612, p27 was dramatically induced ( eightfold), accompanied by induction of apoptosis (Figure 10). This was also true when a tripeptidyl inhibitor LLnV was used (Figure 10). By contrast, exposure of normal WI-38 cells to CEP1612 neither induce p27 to a detectable level nor activate apoptotic death program (Figures 9 and 10). Therefore, CEP1612 is able to selectively accumulate p27 to a critical level in the transformed but not in the normal cells. The treatment of the transformed cells with etoposide only slightly increased the p27 level, but did not induce apoptosis (Figure 10), again arguing that accumulation of p27 to a threshold is associated with induction of apoptosis.

A most recent report has suggested that cycling cells are more sensitive to proteasome inhibitor-induced apoptosis than non-cycling cells such as theymocytes or nonproliferating Rat-1 cells (Lopes et al, 1997). The following evidence argue that the differential activity of CEP1612 in normal and transformed cells is not due to different cell cycle status of these two cell lines. First, the proliferation rates are similar for both WI-38 and WI-38 VA13 cells. Secondly, the basal level of p27, an inhibitor of cell proliferation, is even higher in the transformed than the normal human WI-38 cells (Figure 10c, lanes 4 vs 1). Thirdly, the selective killing of the transformed cells by CEP1612 is tightly associated with a selective, significant accumulation of p27 (Figure 10c). Our data strongly suggest that CEP1612 may have a tumor-selective killing ability.

The mechanism responsible for the selective accumulation of p27 by proteasome inhibitors in the transformed cells in unclear. A higher basal level of p27 in the transformed cells (Figure 10c) may contribute to this 
selectivity. Our results suggest that the abnormal accumulation of p27 may play an important role in the initiation of apoptosis in the transformed cells. We have also realized that other proteasome targets may be involved in the CEP1612-induced apoptosis and tumor-selective action as well. One such candidate target is $\mathrm{NF}-\kappa \mathrm{B}$ (Verma et al, 1995), which has been shown most recently to function as an endogenous apoptosis inhibitor (Beg and Baltimore, 1996). The further studies should focus on how abnormally accumulated p27 crosstalks to the apoptosis initiator(s), how CEP1612 overcomes Bcl-2-mediated protection from apoptosis, and what other proteasome targets are involved in the selective action of proteasome inhibitors on tumor cells.

\section{Materials and Methods}

\section{Materials}

Purified mouse monoclonal antibody to human RB (G3-245) and p21 were purchased from PharMingen (San Diego, CA, U.S.A.); to caspase-3 (CPP32) was from Transduction Laboratories (Lexington, KY, U.S.A.); to human PARP (C-2-10) was from Unité de Santé et Environnement (Québec, Canada). Purified rabbit polyclonal antibody to p27 was from Upstate Biotechnology, Inc. (Lake Placid, NY, U.S.A.). Mouse monoclonal culture supernatant to human RB (XZ55) was a kind gift from Drs. N. Dyson and E. Harlow (Massachusetts General Hospital Cancer Center, Charlestown, MA, U.S.A.). Etoposide, cisplatin, propidium iodide, Hoechst 33258 and other chemicals were obtained from Sigma; YVAD-CMK was from Bachem Bioscience Inc. (King of Prussia, PA, U.S.A.). The dipeptidyl aldehydes CEP1612, CEP1508, and CEP1513, and the inactive semicarbazone analog CEP1601, were described in our earlier publications (Harding et al, 1995; Iqbal et al, 1995). The dipeptidyl $\alpha$-ketoamide CMPD8, a mixture of two isomers, was also described previously (lqbal et al, 1996).

\section{Cell culture}

Human Jurkat T and HL-60 cells were grown in RPMI 1640 (Life Technologies, Inc.) supplemented with $10 \%$ fetal calf serum (Sigma), 100 units $/ \mathrm{ml}$ of penicillin, $100 \mu \mathrm{g} / \mathrm{ml}$ of streptomycin and $2 \mathrm{mM} \mathrm{L}$ glutamine (growth medium). Jurkat $T$ cells overexpressing the murine $\mathrm{Bcl}-2$ oncoprotein or vector alone (provided by Dr. D. Johnson, University of Pittsburgh, PA) were grown in the same growth medium with $0.5 \mathrm{mg} / \mathrm{ml} \mathrm{G} 418$ (Dou et al, 1997; An et al, 1998). Human cancer cell lines of prostate (PC3, DU145), breast (MDA-MB-231, MCF-7) and osteosarcoma (U2-OS), obtained from American Type Culture Collection (ATCC), were also grown in the RPMI growth medium. Human oral (SCC-25; from ATCC) and brain (SNB-19; Welch et al, 1995) cancer cell lines, and normal (WI-38; from ATCC) and SV40transformed human fibroblasts (WI-38 VA13; from ATCC) were grown in DMEM medium containing $10 \%$ fetal calf serum, penicillin, streptomycin and L-glutamine.

\section{Treatment of cells with a proteasome inhibitor}

Cells were treated with either a proteasome inhibitor, a standard anticancer agent (etoposide or cisplatin), or DMSO (vehicle). During this process, morphological changes and cellular detachment (for attached cell lines) were monitored. At each time point, cells were harvested, and used for measurement of apoptosis and other biochemical events. In experiments involving YVAD-CMK, a proteasome inhibitor was first added to Jurkat $\mathrm{T}$ cells. This was followed immediately by dividing the cells into multiple tissue culture flasks. YVAD-CMK was then added to an indicated concentration.

\section{Flow cytometry, nuclear staining and DNA fragmentation assays}

DNA content analysis using flow cytometry was performed as described previously (Nicoletti et al, 1991). To assay nuclear morphology, human leukemia cells, or detached or remaining attached solid tumor cells are washed with PBS, fixed with $70 \%$ ethanol for $1 \mathrm{~h}$ and stained with Hoechst $33258(1 \mathrm{mM})$ for $30 \mathrm{~min}$. The nuclear morphology of cells was visualized by fluorescence microscope (OLYMPUS BH2). DNA fragmentation was assayed as described previously (Grant et al, 1992).

\section{Cell viability assay}

The viability of Jurkat cells was evaluated following treatment for $24 \mathrm{~h}$ with test compounds. At the end of the treatment, cell viability was assessed by an XTT assay of mitochondrial function, using agents purchased from Sigma (St. Louis, MO), and a protocol provided by the manufacturer. Following incubation in XTT solution for $3 \mathrm{~h}$ at $37^{\circ} \mathrm{C}$, absorbance at $450 \mathrm{~nm}$ was read in a spectrophotometer.

\section{Whole cell extracts and Western blot assay}

Whole cell extracts and the enhanced chemiluminescence (ECL) Western blot assay were performed as described previously (An and Dou, 1996).

\section{Acknowledgements}

This work was supported in part by a fund from the Department of Pharmacology, University of Pittsburgh School of Medicine (to Q.P.D.). We thank D. Johnson for providing Jurkat T cells overexpressing Bcl-2 or vector, N. Dyson and E. Harlow for Mouse monoclonal culture supernatant to human RB (XZ55), C. Fattman for technical assistance, R. Kitson for helpful comments, and H.G. Wang (Moffitt Cancer Center) for critical reading of the manuscript.

\section{References}

Alnemri ES, Livingston DJ, Nicholson DW, Salvesen G, Thornberry NA, Wong WW and Yuan J (1996) Human ICE/CED-3 protease nomenclature. Cell 87: 171

An B and Dou QP (1996) Cleavage of retinoblastoma protein during apoptosis: an interleukin $1 \beta$-converting enzyme-like protease as candidate. Cancer Res. 56 : $438-442$

An B, Johnson DE, Jin JR, Antoku K and Dou QP (1998) Bcl-2- and CrmA-inhibitable dephosphorylation and cleavage of retinoblastoma protein during etoposideinduced apoptosis. Int. J. Mol. Med. 1: 131-136

Bartek J, Iggo R, Gannon J and Lane DP (1990) Genetic and immunochemical analysis of mutant $p 53$ in human breast cancer cells. Oncogene 5: 893-899

Beg AA and Baltimore D (1996) An essential role for NF- $\kappa$ B in preventing TNF- $\alpha-$ induced cell death. Science 274: $782-784$

Blagosklonny MV, Wu GS, Omura S and el-Deriry WS (1996) Proteasomedependent regulation of p21 Waf1/Cip1 expression. Biochem. Biophys. Res. Commun. 227: 564-569

Casey G, Lo-Hsueh M, Lopez ME, Vogelstein B and Stanbridge EJ (1991) Growth suppression of human breast cancer cells by the introduction of a wild-type $p 53$ gene. Oncogene 6: 1791-1797 
Chen WD, Otterson GA, Lipkowitz S, Khleif SN, Coxon AB and Kaye FJ (1997) Apoptosis is associated with cleavage of a $5 \mathrm{kDa}$ fragment form $\mathrm{RB}$ which mimics dephosphorylation and modulates E2F binding. Oncogene 14: 1243-1248

Danova M, Giordano M, Mazzini G and Riccardi A (1990) Expression of p53 protein during the cell cycle measured by flow cytometry in human leukemia. Leukemia Res. 14: 417-422

Day ML, Foster RG, Day KC, Zhao X, Humphrey P, Swanson P, Postigo AA, Zhang SH and Dean DC (1997) Cell anchorage regulates apoptosis through the retinoblastoma tumor suppressor/E2F pathway. J. Biol. Chem. 272: 8125-8128

Desoize B (1994) Anticancer drug resistance and inhibition of apoptosis. Anticancer Res. 14: 2291-2294

Dou QP, An B and Will PL (1995) Induction of a retinoblastoma phosphatase activity by anticancer drugs accompanies p53-independent G1 arrest and apoptosis. Proc. Natl. Acad. Sci. USA. 92: 9019-9023

Dou QP (1997) Putative roles of retinoblastoma protein in apoptosis. Apoptosis 2: $5-$ 18

Dou QP, An B, Antoku K and Johnson DE (1997) Fas stimulation induces RB dephosphorylation and proteolysis that is blocked by inhibitors of the ICE protease family. J. Cell. Biochem. 64: 586-594

Drexler HCA (1997) Activation of the cell death program by inhibition of proteasome function. Proc. Natl. Acad. Sci. USA. 94: 855-860

Enari M, Hug H and Nagata S (1995) Involvement of an ICE-like protease in Fasmediated apoptosis. Nature 375: 78-81

Fattman CL, An B and Dou QP (1997) Characterization of interior cleavage of retinoblastoma protein in apoptosis. J. Cell. Biochem. 67: 399-408

Fisher DE (1994) Apoptosis in cancer therapy: Crossing the threshold. Cell 78: 539542

Grant S, Jarvis WD, Swerdlow PS, Turner AJ, Traylor RS, Wallace HJ, Lin PS, Pettit GR and Gewirtz DA (1992) Potentiation of the activity of $1-\beta$-D-arabinofuranosylcytosine by the protein kinase $C$ activator bryostatin 1 in HL-60 cells: association with enhanced fragmentation of mature DNA. Cancer Res. 52: $6270-6278$

Grimm LM, Goldberg AL, Poirier GG, Schwartz LM and Osborne BA (1996) Proteasomes play an essential role in thymocyte apoptosis. EMBO J. 15: 38353844

Harding CV, France J, Song R, Farah JM, Chatterjee S, Iqbal M and Siman R (1995) Novel dipeptide aldehydes are proteasome inhibitors and block the MHC-1 antigen-processing pathway. J. Immunol. 155: 1768-1775

Harrison DJ (1995) Molecular mechanisms of drug resistance in tumours. J. Pathol. 175: $7-12$

Hinds PW, Mitnacht S, Dulic V, Arnold A, Reed SI and Weinberg RA (1992) Regulation of retinoblastoma protein functions by ectopic expression of human cyclins. Cell 70: 993-1006

Hochstrasser M (1995) Ubiquitin, proteasomes, and the regulation of intracellular protein degradation. Curr. Opin. Cell Biol. 7: 215-223

Imajoh-Ohmi S, Kawaguchi T, Sugiyama S, Tanaka K, Omura S and KikuchiH(1995) Lactacystin, a specific inhibitor of the proteasome, induces apoptosis in human monoblast U937 cells. Biochem. Biophy. Res. Commu. 217: 1070-1077

Iqbal M, Chatterjee S, Kauer JC, Das M, Messina P, Freed B, Biazzo W and Siman R (1995) Potent inhibitors of proteasome. J. Med. Chem. 38: 2276-2277

lqbal M, Chatterjee S, Kauer JC, Mallamo JP, Messina PA, Reiboldt A and Siman R (1996) Potent $\alpha$-ketocarbonyl and boronic ester derived inhibitors of proteasome. Bioorgan. Medici. Chem. Letters 6: 287-290

Iwamoto KS, Mizuno T, Ito T, Tsuyama N, Kyoizumi S and Seyama T (1996) Gain-offunction p53 mutations enhance alteration of the T-cell receptor following Xirradiation, independently of the cell cycle and cell survival. Cancer Res. 56: 3862-3865

Jacobson MJ, Weil M and Raff MC (1997) Programmed cell death in animal development. Cell 88: $347-354$

Janicke RU, Walker PA, Lin XY and Porter AG (1996) Specific cleavage of the retinoblastoma protein by an ICE-like protease in apoptosis. EMBO J. 15:69696978

Kellen JA (1994) Molecular interrelationships in multidrug resistance. Anticancer Res. 14: $433-436$
Lazebnik YA, Kaufmann SH, Desnoyers S, Poirier GG and Earnshaw WC (1994) Cleavage of poly(ADP-ribose polymerase by a proteinase with properties like ICE. Nature 371: $346-347$

Lee S, Christakos S and Small MB (1993) Apoptosis and signal transduction: clues to a molecular mechanisms. Curr. Opin. Cell Biol. 5: 286-291

Linette GP, Li Y, Roth K and Korsmeyer SJ (1996) Cross talk between cell death and cell cycle progression: $\mathrm{Bcl}-2$ regulates NFAT-mediated activation. Proc. Natl. Acad. Sci. USA. 93: 9545-9552

Lopes UG, Erhardt P, Yao R and Cooper GM (1997) p53-dependent induction of apoptosis by proteasome inhibitors. J. Biol. Chem. 272: 12893-12896

Martin SJ and Green DR (1995) Protease activation during apoptosis: death by a thousand cuts? Cell 82: 349-352

Miyashita T and Reed JC (1993) Bcl-2 oncoprotein blocks chemotherapy-induced apoptosis in a human leukemia cell lines. Blood 81: 151-157

Morana SJ, Wolf CM, Li J, Reynolds JE, Brown MK, Eastman A (1996) The involvement of protein phosphatases in the activation of ICE/CED-3 protease intracellular acidification, DNA digestion, and apoptosis. J. Biol. Chem. 271: $18263-18271$

Nicoletti I, Migliorati G, Pagliacci MC, Grignani F and Riccardi C (1991) A rapid and simple method for measuring thymocyte apoptosis by propidium iodide staining and flow cytometry. J. Immunol. Methods 139: 271-279

Pagano M, Tam SW, Theodoras AM, Beer-Romero P, Del Sal G, Chau V, Yew PR Draetta GF and Rolfe M (1995) Role of the ubiquitin-proteasome pathway in regulating abundance of the cyclin-dependent kinase inhibitor p27. Science 269: $682-685$

Rivett AJ (1993) Multicatalytic proteinase complexes. Biochem. J. 291: 1-10

Rock KL, Gramm C, Rothstein L, Clark K, Stein R, Dick L, Hwang D and Goldberg AL (1994) Inhibition of the proteasome block the degradation of most cell proteins and generation of peptides presented on MHC class I molecules. Cell 78: 761 771

Sadoul R, Fernandez PA, Quiquerez AL, Martinou I, Maki M, Schroter M, Becherer JD, Irmler M, Tschopp J and Martinou JC (1996) Involvement of the proteasome in the programmed cell death of NGF-deprived sympathetic neurons. EMBO J. 15: $3845-3852$

Shinohara K, Tomioka M, Nakano H, Tone S, Ito H and Kawashima S (1996) Apoptosis induction resulting from proteasome inhibition. Biochem. J.317:385388

Tan X, Martin SJ, Green DR and Wang JYJ (1997) Degradation of retinoblastoma protein in tumor necrosis factor- and CD95-induced cell death. J. Biol. Chem 272: $9613-9616$

Tanimoto Y, Onishi Y, Hashimoto S and Kizaki H (1997) Peptidyl aldehyde inhibitors of proteasome induce apoptosis rapidly in mouse lymphoma RVC cells. J. Biochem. (Tokyo) 121: 542-549

Thornberry NA, Bull HG, Calaycay JR, Chapman KT, Howard AD, Kostura MJ, Miller DK, Molineaux SM, Weidner JR and Aunins J (1992) A novel heterodimeric cysteine protease is required for interleukin- $1 \beta$ processing in monocytes. Nature 356: $768-774$

Verma IM, Stevenson JK, Schwarz EM, Antwerp DV and Miyamoto S (1995) Rel/NF$\kappa \mathrm{B} / \mathrm{I}_{\kappa} \mathrm{B}$ family: intimate tales of association and dissociation. Genes Dev. 9: 2723-2735

Wang HC and Reed JC (1998) Mechanisms of Bcl-2 protein function. Histol. Histopathol. 13: $521-530$

Wang S, Miura M, Jung Y-K, Zhu H, Li E and Yuan J (1998) Murine caspase-11, an ICE-interacting protease, is essential for the activation of ICE. Cell 92: 501-509

Wasserman K, Kitson RP, Rivett AJ, Sweeney ST, Gabauer MK, Herberman RB, Watkins SC and Goldfarb RH (1994) Nongranular proteolytic enzymes of rat IL-2 activated natural killer cells. II. Purification and identification of rat A-NKP1 and A NKP2 as constituents of the multicatalytic proteinase (Proteasome) complex. J. Cell Biochem. 55: 133-145

Welch WC, Morrison RS, Gross JL, Gollin SM, Kitson RB, Goldfarb RH, Giuliano KA Bradley MK and Kornblith PL (1995) Morphologic, immunologic, biochemical, and cytogenetic characteristics of the human glioblastoma-derived cell line, SNB-19. In Vitro Cell. Dev. Biol. 31: 610-616 